\title{
Levels of yeast and its by-products on pacu juveniles feeding ${ }^{1}$
}

\author{
André Luiz Watanabe ${ }^{2}$, Elisabete Maria Macedo Viegas² ${ }^{2}$ Lígia Uribe Gonçalves $^{2}$
}

\author{
1 Pesquisa patrocinada pela Fapesp e pelo CNPq. \\ 2 Universidade de São Paulo, Faculdade de Zootecnia e Engenharia de Alimentos, Departamento de Zootecnia, Av. Duque de Caxias \\ Norte, 225, CEP: 13635-900, Pirassununga, SP.
}

ABSTRACT - This study was conducted to evaluate the inclusion of two levels (2.5 e $5.0 \%$ ) of dried yeast (Saccharomyces cerevisiae) and its by-products, disrupted yeast cells and yeast cell wall in diets for juveniles of pacu (Piaractus mesopotamicus). Production performance, body and plasmatic composition indexes were evaluated. Seven isoproteic (26\% digestible protein) and isoenergetic ( $3.100 \mathrm{kcal}$ digestible energy) diets were formulated containing increased levels of each ingredient. The diets were supplied for 86 days, "ad libitum". Yeast and by-products increase feed efficiency and protein use, when compared to the control diet. Carcass composition and plasmatic (glucose, cortisol, uric acid, urea and plasmatic protein) levels are not affected by the test ingredient supplementation.

Key Words: Piaractus mesopotamicus, pre-biotic, production performance, Saccharomyces cerevisiae, yeast by-products

\section{Níveis de levedura e derivados na dieta de juvenis de pacu}

\begin{abstract}
RESUMO - Este estudo foi realizado com o objetivo de avaliar os efeitos da suplementação de dois níveis $(2,5$ e $5,0 \%)$ de levedura íntegra desidratada (Saccharomyces cerevisiae) e seus derivados, autolisado e parede celular, em dietas para juvenis de pacu $(11,98 \mathrm{~g} \mathrm{e} 8,5 \mathrm{~cm})$. Foram avaliados o desempenho produtivo, a composição corporal e os parâmetros plasmáticos de juvenis de pacu. Utilizaram-se sete dietas isoproteicas (26\% de proteína digestível por $\mathrm{kg}$ de ração) e isoenergéticas $(3.100 \mathrm{kcal}$ de energia digestível por kg de ração), cada uma com um nível de cada ingrediente-teste e mais uma dieta controle (sem adição de levedura). A suplementação da levedura e de derivados realizada durante 86 dias melhorou a eficiência alimentar e a utilização proteica pelos juvenis de pacu em comparação à dieta sem adição desses ingredientes. A composição de carcaça e os níveis plasmáticos (ureia, ácido úrico, proteína, cortisol e glicose) não são afetados pela suplementação dos ingredientes-teste.
\end{abstract}

Palavras-chave: derivados de levedura, desempenho produtivo, Piaractus mesopotamicus, prebiótico, Saccharomyces cerevisiae

\section{Introduction}

The intensification of the production process has triggered events which harm the balance among the factors that compose the production system, such as nutritional needs, infective/parasitological pathologies and the decrease of water quality, causing losses on the production. In order to smooth those losses, drugs and chemical substances might be used as treatment and/or as feeding additive; however, they present several use restrictions (Lara Flores et al., 2003).

The yeast (Saccharomyces cerevisiae) included in the animal diet might be an alternative to the increase in the production efficiency, including aquiculture. Thus, it is aimed the understanding of the mechanisms which include the action of components such as mannose polymers linked to peptides (mannoproteins), glucose polymers (glucans) and quitin (Li \& Gatlin, 2004). Those components may act in a positive way in the animal organism, affecting certain events, for instance, the colonization of pathogenic bacteria in the intestines, the neutralization of micotoxines, the immunostimulation (Romero \& Gomez-Basuari, 2003; Grieshop, 2003; Flickimger, 2003) and activation of macrophagos, increase of the phagocytosis activity and quantity and activation of the lynphocites, in the plasmatic immunoglobuline of lysoenzymes and also in the increase of antibody production (Sakai, 1999; Gannam, 2005).

The discussions on the use of this polysaccharide cover the dosing and the ministration period, besides explanations about the mechanisms and its function on animal physiology as an prophylactic agent and in the 
treatment of diseases caused by pathogenic elements of latent and/or sublethal action (Gannan, 2005).

Besides the polysaccharides, the yeast is a source of nucleic acids (Rumsey et al., 1992), known for its property of interfering in the organism defense mechanisms of several aquatic species (Li \& Gatlin III, 2003) and directly related to numerous physiological and genetic functions, working as mediators of energy metabolism (Li \& Gatlin III, 2004). Hence, the immunostimulators represent an important and promising tool for aquiculture, as they increase productivity and improve animal resistance.

The aim of this work was to assess the effect of adding yeast and its by-products into the diet regarded to performance, body constitution and the plasmatic parameters of pacu juveniles.

\section{Material and Methods}

It was used a closed circuit of cycling water composed of 35 glass fiber boxes $(60.0 \mathrm{~cm} \times 55.0 \mathrm{~cm} \times 50.0 \mathrm{~cm})$ with net storage capacity of $130 \mathrm{~L}$, in which the cycling flow enabled approximately seven daily water exchanges. The limnological parameters were daily monitored by using a probe (Horiba, model U-10) and the content of ammonia and nitrite was assessed weekly by using kits sold in the market.

A group of 350 pacu juveniles $(11.98 \pm 1.72 \mathrm{~g})$ was used. They were divided into 35 groups of 10 animals each. Beforehand, the fish rested for 15 days and were freely fed with the experimental ration twice a day (at 8 a.m. and 7 p.m.) during 86 days.

It was applied an complete random method in a factorial scheme with an addition $3 \times 2+1$ diet of five repetitions, composed by the three test-ingredients (whole yeast, autolyzed yeast, and cell wall), two degrees of the testingredients $(2.5$ e $5.0 \%)$ and one more control (without inclusion of yeast or by-products), adding up seven experimental days.

The choice and selection of the ingredients were based on their availability, cost and centesimal constitution, meeting the nutritional requirements for the species (Fernandes et al., 2000; 2001; Abimorad \& Carneiro, 2004; Ozório et al., 2004; Fernandes et al., 2004). To guarantee the nutritional efficiency of the diets, besides the values of gross energy and crude protein, the digestive values of the ingredients used for omnivorous species were also used and established when such figures were not available for the Piaractus line.

The determination of the nutritional constitution of the ingredients (Table 1) was accomplished according to methodological procedures of AOAC (1990), being produced extruded, isoproteic and isoenergetic rations (Table 2). For the determination of the centesimal constitution, the conversion factor 5.8 was used for to compute yeast and by-products proteic values, as the nitrogen contribution is, partially, due to the nitrogen bases present in the nucleic acids (Sgarbieri et al., 1999).

During the experimental period, four biometries were accomplished (0,30, 60 and 86 days) to measure length and weight of the samples. These procedures were made by sedating the animals with benzocaine $(0.03 \mathrm{~g} / \mathrm{L})$. At the last assessment, after acquiring the biometric data, two animals of each parcel were randomly selected; one for blood sampling and the other for body composition determination, in which the animal was sacrificed by injection of lethal doses of the same anesthetic $(3.0 \mathrm{~g} / \mathrm{L})$.

The assessment of the zootechnical profit was made based on data of 350 fish, individually inspected through the four biometric procedures. To assess the performance, the ration consumption, weight gain, food conversion, proteic efficiency rate and the specific growth rate were assessed.

Table 1 - Nutritional constitution of the ingredients used in the formulation of the diets for performance trial

\begin{tabular}{|c|c|c|c|c|c|c|c|c|c|}
\hline Ingredient & $\begin{array}{c}\text { Dry } \\
\text { matter } \\
(\%)\end{array}$ & $\begin{array}{c}\text { Crude } \\
\text { protein } \\
(\%)\end{array}$ & $\begin{array}{c}\text { Ether } \\
\text { extract } \\
(\%)\end{array}$ & $\begin{array}{l}\text { Crude } \\
\text { fiber } \\
(\%)\end{array}$ & $\begin{array}{c}\text { Mineral } \\
\text { matter } \\
(\%)\end{array}$ & $\begin{array}{c}\text { Non- } \\
\text { nitrogen } \\
\text { extract }(\%)\end{array}$ & $\begin{array}{l}\text { Calcium } \\
(\%)\end{array}$ & $\begin{array}{c}\text { Total } \\
\text { phosphorus } \\
(\%)\end{array}$ & $\begin{array}{c}\text { Gross } \\
\text { energy } \\
(\mathrm{kcal} / \mathrm{kg})\end{array}$ \\
\hline Soybean bran & 87.47 & 51.61 & 1.13 & 5.84 & 6.73 & 34.68 & 0.21 & 0.85 & 4586 \\
\hline Fish flour & 94.32 & 59.94 & 8.10 & 1.27 & 27.05 & 3.64 & 5.53 & 2.11 & 4242.5 \\
\hline Corn gluten & 91.59 & 69.09 & 1.99 & 1.02 & 1.34 & 26.56 & 0.01 & 0.15 & 5485.0 \\
\hline Broken rice & 89.16 & 8.53 & 1.63 & 0.42 & 0.49 & 88.94 & 0.02 & 0.25 & 4149.0 \\
\hline Corn (grain) & 89.11 & 10.38 & 4.17 & 2.57 & 1.02 & 81.86 & 0.03 & 0.19 & 4284.0 \\
\hline Wheat bran & 90.53 & 17.87 & 3.44 & 9.75 & 5.74 & 63.20 & 0.06 & 1.01 & 4289.0 \\
\hline Whole yeast & 93.53 & 38.70 & 0.34 & 0.44 & 3.61 & 56.92 & 0.01 & 0.74 & 4398.0 \\
\hline Autolyzed yeast & 94.50 & 39.14 & 0.10 & 0.29 & 6.22 & 54.24 & 0.06 & 0.64 & 4421.0 \\
\hline Cell wall & 93.23 & 37.46 & 0.22 & 0.34 & 4.13 & 57.85 & 0.04 & 0.71 & 4490.0 \\
\hline Soybean oil ${ }^{1}$ & & & & & & & & & 9333.0 \\
\hline
\end{tabular}


Table 2 - Constitution of the experimental diets applied to the zootechnical trial

\begin{tabular}{|c|c|c|c|c|c|c|c|}
\hline \multirow[b]{2}{*}{ Ingredient } & \multirow[b]{2}{*}{ Control } & \multicolumn{2}{|c|}{ Entire yeast } & \multicolumn{2}{|c|}{ Autolyzed yeast } & \multicolumn{2}{|c|}{ Cell wall } \\
\hline & & 2.5 & 5.0 & 2.5 & 5.0 & 2.5 & 5.0 \\
\hline Entire yeast & - & 2.5 & 5.0 & - & - & - & - \\
\hline Cell wall & - & - & - & - & - & 2.5 & 5.0 \\
\hline Soybean bran & 20 & 19 & 19 & 19 & 19 & 17.5 & 18 \\
\hline Fish flour & 17 & 17 & 14.5 & 17 & 15.1 & 16.5 & 16 \\
\hline Corn (grain) & 15 & 14.5 & 14.5 & 14.5 & 15 & 15 & 14 \\
\hline Wheat bran & 17 & 16.5 & 16 & 16.5 & 16 & 16.5 & 16 \\
\hline Soybean oil & 0.5 & 0.5 & 0.5 & 0.5 & 0.5 & 0.5 & 0.5 \\
\hline Mineral and vitamin supplement ${ }^{2}$ & 0.5 & 0.5 & 0.5 & 0.5 & 0.5 & 0.5 & 0.5 \\
\hline Nutritional & & & & $(\%)$ & & & \\
\hline Dry matter & 97.73 & 96.64 & 96.67 & 96.07 & 97.76 & 96.99 & 96.80 \\
\hline Mineral matter & 7.24 & 7.19 & 6.63 & 7.28 & 7.13 & 7.09 & 6.99 \\
\hline Non-nitrogenic extract & 56.52 & 56 & 57.32 & 57.02 & 56.32 & 56.83 & 57.50 \\
\hline Gross energy (kcal/kg) & 4319.41 & 4339.88 & 4329.83 & 4298.81 & 4364.94 & 4345.89 & 4302.97 \\
\hline$(\text { Digestible energy })^{1}$ & $(3162.17)$ & $(3134.1)$ & $(3105.8)$ & $(3134.8)$ & (3104) & $(3151.1)$ & $(3111.6)$ \\
\hline Calcium $^{1}$ & 0.94 & 0.93 & 0.80 & 0.94 & 0.84 & 0.91 & 0.89 \\
\hline Total phosphorus ${ }^{1}$ & 0.72 & 0.73 & 0.69 & 0.73 & 0.70 & 0.71 & 0.71 \\
\hline Lysine $^{1}$ & 1.46 & 1.51 & 1.52 & 1.51 & 1.54 & 1.38 & 1.36 \\
\hline Methionine + cistine $^{1}$ & 1.15 & 1.14 & 1.13 & 1.14 & 1.13 & 1.12 & 1.08 \\
\hline Tryptophan ${ }^{1}$ & 0.30 & 0.31 & 0.31 & 0.31 & 0.31 & 0.29 & 0.29 \\
\hline
\end{tabular}

${ }^{1}$ Values computed by the Super Crac 4.2 matrix.

${ }^{2}$ Composition of the mineral and vitamin supplement Supre Mais (guarantee levels per kg of ration): minerals (in mg): $\mathrm{Fe}-50.0 ; \mathrm{Cu}-3.0 ; \mathrm{Mn}-20.0 ; \mathrm{Zn}-150.0$; I - 0.10; Co - 0.01 e Se - 0.10; vitamins: A - 600.0 UI; D3 - 1,000.0 UI; E - 60.0 mg; K3 - 12.0 mg; B1 - 24.0 mg; B2 - 24.0 mg; B6 - 20.0 mg; B12 - 24.0 mg; folic acid $-6.0 \mathrm{mg}$; calcium pantothenate $-60.0 \mathrm{mg}$; ascorbic acid $-240.0 \mathrm{mg}$; biotine $-0.24 \mathrm{mg}$; coline $-325.0 \mathrm{mg}$; niacin $-120.0 \mathrm{mg}$.

For the analyses of the blood components, $1 \mathrm{~mL}$ of blood from the tail vein of each fish was collected by using syringes previously heparinizated. The samples were kept in ice. They were centrifuged (3,000 rpm) for five minutes (Barone, 2006) and the floating material (plasma) was taken and stored under $-18^{\circ} \mathrm{C}$ temperature for further analyses. It was applied a final dot color enzymatic methodology for urea $(\mathrm{mg} / \mathrm{dL})$, glucose $(\mathrm{mg} / \mathrm{dL})$ and uric acid $(\mathrm{mg} / \mathrm{dL})$, a final dot color procedure for protein $(\mathrm{g} / \mathrm{dL})$ and enzymatic imunosampling method for cortisol $(\mu \mathrm{g} / \mathrm{dL})$.

The sample readings were done by ELISA Labsystem Multiskan Version 8.0 reader, and the concentrations values of these plasmatic components were processed by the values of sampling absorption and standard curve, determined by the software Labsystems Gênesis V3.03.

The statistical analysis was made according to the specific guideline adopted, resulting in distinct ways of analysis. The first step was to analyze the variance (ANOVA) for all data and, when significant difference was not found, it was finished. When there was significant difference, average comparison (at $5 \%$ of significance) was promoted by applying orthogonal contrasts, which is a method recommended for experimental practices in factorial, covering a control diet, which does not enable the traditional variance analysis (Nogueira \& Corrente, 2000; Corrente et al., 2001; Nogueira, 2004). In that cases, the used contrasts were the following: control comparison versus factorial (for all diets with yeast), comparison among the yeast levels ( 2.5 and 5.0\%), comparison among the yeast types (whole yeast. autolyzed yeast and cell wall) and the interaction between level and type of yeast. Because the interactions did not show significant difference, there was no need of additional works. Those analyses were performed by using the statistical applicative SAS 9.1 (2004).

\section{Results and Discussion}

The mean values observed for $\mathrm{pH}$, temperature, dissolved oxygen, salinity, conductivity, ammonia and nitrite during the experimental period were: $7.22 \pm 0.43$; $27.17 \pm 0.47^{\circ} \mathrm{C} ; 5.02 \pm 0.97 \mathrm{mg} / \mathrm{L} ; 0 \%$ e $0.192 \pm 0.07 \mathrm{mS} / \mathrm{cm}$; 0.0 a $0.25 \mathrm{ppm} ; 0.0-1.0 \mathrm{mg} / \mathrm{L}$, respectively, and meet the requirements for fish farming in closed circuit intensive production systems (Pavanelli et al., 2002; Ozório et al., 2004).

During the performance experiment ( 86 days), mortality was not observed in the 35 experimental units. The variance 
analysis identified difference $(\mathrm{P}<0.05)$ in ration consumption and food conversion indexes (Table 3 ). The consumption of ration by the fish fed by using the control diet was higher than that by the other fish, which may have triggered low feeding performance.

The higher consumption by the fish which were not fed with yeast in the diet can be explained by the difference of ration tastes, fact that caused distinction in feeding behavior. Pereira da Silva \& Pezzato (2000) noticed thoses differences in several ingredients used for diet constitution for tilapias; the sugar-cane yeast was classified as having medium-level taste appeal, different from the animal-derived ingredients (dried entire egg, chrysalides flour, fish, shrimp meat). The changes in sensorial quality may be significant and trigger loss of productivity. A reason for that is the high level of nucleic acids present in the constitution of $S$. cerevisiae (Rumsey et al., 1991a).

Furthermore, the animals fed with yeast and by-product supplementation ingested less quantity of food when compared to the control, but the was no loss of performance, which suggests a better feeding efficiency caused by the test supplementation. That better capacity in using diet nutrients, which triggered better performance, might be explained by the fact that the diets present higher amounts of insoluble polysaccharides (glucans) and manano proteins Sgarbieri et al., 1999; Scapinello et al., 2001ab), known for increasing the production performance of the animals (Sakai, 1999; Romero \& Gomez-Basuari, 2003; Grieshop, 2003; Flickinger, 2003).

These components, the non-amilaceous polysaccharides ( $\beta$-glucans), can represent $30 \%$ of the dry weight of the cell and up to $60 \%$ of the constitution of that structure (Romero \& Gomez-Basuari, 2003) and show the ability to increase fish growth (Sakai, 1999; Li \& Gatlin III, 2004; Gannam, 2005). Unfortunately, it was not possible to quantify such components in the ingredients used. It is known that the nutritional constitution of yeast might change not only due to the processes to which it is subjected, but also owing to its origins and the environment in which it is cultivated, fact that may cause wide variability of the responses for this sort of supplementation.
Another factor that may increase the feeding efficiency is the production of volatile fatty acids (acetate and propionate) derived from the insoluble fiber fermentation present in yeast diets, which may increase the energy availability (Rimmer \& Wiebe, 1987; Smith et al., 1996). It was not possible to state that in this study that those substances were used in the digestive process of pacu, since there was no clear determination of the production of these compound, nor the quantification of the nonamilaceous carbohydrates present in the ingredients and in the diets. However, all the fish fed by using the yeast and by-product diets presented better use of the proteic fraction and food conversion, stated by the significant difference $(\mathrm{P}<0.01)$ among the control diet and those which contained any sort of yeast (Table 3 ).

In this study it was not noticed ( $\mathrm{P}>0.05$ or 0.01$)$ the influence of the yeast sub-product processing system over the performance of pacu alevines, different from what is said by other authors regarded to the existence of feeding and nutritional benefits when autolyzed yeast is used (broken cell wall), due to greater availability and use of S. cerevisiae nutrients by other fish species (Rumsey et al., 1991b).

It was not noticed any variation tendency in the zootechnical indexes due to the increase from 2.5 to $5.0 \%$ in the contents of each ingredient, which indicates in this case that the juveniles of pacu did not show any proportional response to the increase in the yeast addition. The improvement of feeding efficiency and of protein use in the performance of $P$. mesopotamicus could be accomplished even when low levels of yeast and/or by-products were used, as reported by Li \& Gatlin III (2003; 2004; 2005), who verified similar results to the "striped bass", as a better yield, due to the autolyzed ingestion effect, which might be related to efficiency in the improvement of the non-specific immune system.

The plasmatic parameters did not differ $(\mathrm{P}>0.05)$ among the diets (Table 4$)$. The urea and uric acid present in the plasma may be used as indicators of drawbacks caused by the excessive ingestion of non-proteic nitrogen. In this case, a great amount of nucleic acids might result in toxic

Table 3 - Zootechnical performance parameters for juveniles of pacu

\begin{tabular}{|c|c|c|c|c|c|c|c|c|c|}
\hline \multirow[b]{2}{*}{ Item } & \multicolumn{2}{|c|}{ Whole yeast } & \multicolumn{2}{|c|}{ Autolyzed yeast } & \multicolumn{2}{|c|}{ Cell wall } & \multirow[b]{2}{*}{ Control } & \multirow[b]{2}{*}{$\mathrm{CV}(\%)$} & \multirow[b]{2}{*}{ EPM } \\
\hline & $2.5 \%$ & $5.0 \%$ & $2.5 \%$ & $5.0 \%$ & $2.5 \%$ & $5.0 \%$ & & & \\
\hline Feed intake $(\mathrm{g})$ & 735.55 & 844.19 & 930.39 & 832.97 & 755.73 & 898.57 & 990.55 & 13.45 & 51.47 \\
\hline Feed conversion & 1.29 & 1.24 & 1.19 & 1.23 & 1.32 & 1.18 & 1.40 & 8.57 & 0.05 \\
\hline Protein efficiency rate & 2.33 & 2.39 & 2.55 & 2.48 & 2.25 & 2.52 & 2.15 & 8.42 & 0.09 \\
\hline Specific growth rate $(\% /$ day $)$ & 1.86 & 2.04 & 2.17 & 2.02 & 1.88 & 2.13 & 2.08 & 8.71 & 0.08 \\
\hline
\end{tabular}


effects, as well as metabolic disturbance triggered by the uric acid and urea production, produced from nitrogen bases (purines) (Rumsey et al., 1992; Moraes et al., 1995). Some species are able to degrade these compounds as a consequence of uricase activities, identified in the liver of carnivore fish (Rumsey et al., 1991a) and also due to their ability to synthesize non-essencial amino acids on account of the nucleotide availability (Rumsey et al., 1992). Thus, it is supposed that pacu specie also has this ability, as it was not observed increase in the amount of urea or uric acid with the addition of yeast and by-products in the ration.

The pacus fed with the diets did not present significant changes in the levels of cortisol and plasmatic glucose, hence, maybe, there was no participation of the testingredients in such a way they could interfere with the concentration level of these compounds, which are direct indicators of the immune system participation face to the occurrence of stressing-out events.

Moreover, the activity of the immune system can be indirectly characterized by the increase in the indexes of plasmatic protein (albumins and globulins). Some authors affirm that such fact is related to the role of nucleotides (Choudhury et al., 2005), but it is was not possible to notice throughout this study any difference in the amount of seric protein produced by fish.

The yeast supplementation did not provide difference ( $\mathrm{P}>0.05$ ) among the indexes of carcass constitution (Table 5). Baccarin \& Pezzato (2001) and Li et al. (2005) observed changes in the body constitution of fish supplemented with S. cerevisiae, which might cause a zoothecnical drawback due to the reduction of the proteic concentration and the storage of lipids. Those researchers reported that the biological value of protein that come from yeast presents imbalance of amino acids, resulting in the reduction of protein synthesis, turning it into energetic reserves.

The amplification of lipids deposition might also be proportional to the amount of nucleotides in the diet, explained by a possible action of those compounds in the lipid metabolism of some tissues (Hisano et al., 2007). Hence, there is the need for researches emphasize to the use of yeast and by-products for indigenous fish feeding, mainly those with more commercial interest.

Table 4 - Plasmatic indexes of glucose, protein, urea, uric acid and corisol of pacus after 86 days of feeding

\begin{tabular}{|c|c|c|c|c|c|c|c|c|c|}
\hline Item & \multicolumn{2}{|c|}{ Whole yeast } & \multicolumn{2}{|c|}{ Autolyzed yeast } & \multicolumn{2}{|c|}{ Cell wall } & Control & CV (\%) & EPM \\
\hline Glucose (mg/dL) & 125.68 & 104.55 & 104.59 & 109.82 & 125.60 & 96.89 & 112.80 & 27.10 & 13.50 \\
\hline Urea $(\mathrm{mg} / \mathrm{dL})$ & 14.72 & 14.23 & 13.62 & 13.78 & 13.17 & 14.39 & 14.76 & 13.45 & 0.85 \\
\hline Uric acid $(\mathrm{mg} / \mathrm{dL})$ & 1.83 & 2.00 & 1.97 & 1.69 & 1.89 & 1.95 & 1.70 & 14.72 & 0.12 \\
\hline Cortisol $(\mu \mathrm{g} / \mathrm{dL})$ & 15.40 & 11.64 & 13.41 & 11.73 & 17.36 & 16.23 & 17.28 & 28.59 & 1.88 \\
\hline
\end{tabular}

Table 5 - Chemical body constitution (\%) of pacus fed with test diets

\begin{tabular}{|c|c|c|c|c|c|c|c|c|c|}
\hline \multirow[b]{2}{*}{ Item } & \multicolumn{2}{|c|}{ Whole yeast } & \multicolumn{2}{|c|}{ Autolyzed yeast } & \multicolumn{2}{|c|}{ Cell wall } & \multirow[b]{2}{*}{ Control } & \multirow[b]{2}{*}{ CV (\%) } & \multirow[b]{2}{*}{ EPM } \\
\hline & $2.5 \%$ & $5.0 \%$ & $2.5 \%$ & $5.0 \%$ & $2.5 \%$ & $5.0 \%$ & & & \\
\hline Humidity & 65.93 & 65.39 & 66.71 & 66.59 & 66.23 & 65.66 & 65.72 & 1.48 & 0.44 \\
\hline Crude protein & 15.3 & 15.36 & 15.81 & 15.5 & 15.44 & 15.44 & 15.71 & 3.26 & 0.23 \\
\hline Etherl extract & 13.64 & 13.99 & 12.52 & 12.55 & 13.14 & 13.79 & 13.19 & 7.85 & 0.46 \\
\hline Mineral matter & 4.09 & 4.08 & 3.77 & 3.99 & 4.08 & 3.94 & 4.13 & 6.16 & 0.11 \\
\hline
\end{tabular}

\section{Conclusions}

The supplementation with 2.5 and $5 \%$ of whole yeast or by-products in the pacu diets has a positive effect on the feeding efficiency and use of dietetic protein, and does not show undesired effects on the body constitution and on proteic metabolism. The cell breaking process (autolyzed) does not increase the efficiency of the use of yeast nutrients. Thus, the entire cell can be preferably used, as it is a low-cost ingredient and presents larger availability.

\section{Aknowledgments}

The authors aknowledged the Fundação de Amparo à Pesquisa do Estado de São Paulo (FAPESP), for the financial support to the project and to the Conselho Nacional de Desenvolvimento Científico e Tecnológico (CNPq), for the Master degree scholarship given to the first author. 


\section{References}

ABIMORAD, E.G.; CARNEIRO, D.J. Métodos de coleta de fezes e determinação dos coeficientes de digestibilidade da fração protéica e da energia de alimentos para o pacu, Piaractus mesopotamicus (Holmberg, 1887). Revista Brasileira de Zootecnia, v.33, n.5, p.1101-1109, 2004.

ASSOCIATION OF OFFICIAL ANALYTICAL CHEMISTS - AOAC. Official methods of analysis of the Association of Official Agricultural Chemists. 12.ed. Washington: AOAC, 1990. $1298 \mathrm{p}$.

BACCARIN, A.E.; PEZZATO, L.E. Efeito da utilização de levedura desidratada de álcool em dietas para a tilápia do Nilo. Pesquisa Agropecuária Brasileira, v.36, n.3, p.549-556, 2001 .

BARONE, A.P.C. Efeito do maracujá (Passiflora incarnata L. 1753) sobre o bem-estar da tilápia do Nilo (Oreochromis niloticus L. 1759). 2006. 72f. Dissertação (Mestrado em Zootecnia) - Faculdade de Zootecnia e Engenharia de Alimentos/ Universidade de São Paulo, Pirassununga.

CHOUDHURY, D.; PAL, A.K.; SAHU, N.P. et al. Dietary yeast RNA supplementation reduces mortality by Aeromonas hydrophila in rohu (Labeo rohita L.) juveniles. Fish \& Shellfish Immunology, v.19, n.3, p.281-291, 2005.

CORRENTE, J.E.; NOGUEIRA, M.C.S.; COSTA, B.M. Contrastes Ortogonais na análise do controle de volatilização de amônia em compostagem. Scientia Agricola, v.58, n.2, p.407-412, 2001 .

FERNANDES, J.B.K.;CARNEIRO, D.J.; SAKOMURA N.K. Fontes e níveis de proteína bruta em dietas para alevinos de pacu (Piaractus mesopotamicus). Revista Brasileira de Zootecnia, v.29, n.3, p.646-653, 2000.

FERNANDES, J.B.K.;CARNEIRO, D.J.; SAKOMURA N.K. Fontes e níveis de proteína bruta em dietas para juvenis de pacu (Piaractus mesopotamicus). Revista Brasileira de Zootecnia, v.30, n.3, p.617-626, 2001.

FERNANDES, J.B.K; LOCHMANN, R.; BOCANEGRA, F.A. Apparent digestible energy and nutrient digestibility coefficients of diet ingredients for pacu Piaractus brachypomus. Journal of the World Aquaculture Society, v.35, n.2, p.237-244, 2004.

FLICKINGER, E.A. Oligosaccharides as functional foods: can we improve gut health? Nutritional Biotechnology in the Feed and Food Industries. In: ALLTECH'S SYMPOSIUM, 19., 2003, Nottingham. Proceedings... Nottingham, 2003. p.345-353.

GANNAM, A. Immunostimulants in fish diets. In: SIMPÓSIO DE NUTRIÇÃO E SAÚDE DE PEIXES, 1., 2005, Botucatu. Anais... Botucatu, 2005. p.93-102.

GRIESHOP, C.M. The interaction of nutrition and the immune system: a discussion on the role of energy, protein and oligosaccharides. Nutritional biotechnology in the feed and food industries. In: ALLTECH'S NINETEENTH SYMPOSIUM, 9., 2003, Nottingham. Proceedings... Nottingham, 2003. p.499-507.

HISANO, H.; NARVÁEZ-SOLARTE, W.V.; BARROS, M.M. et al. Desempenho produtivo de alevinos de tilápias-do-nilo alimentados com levedura e derivados. Pesquisa Agropecuária Brasileira, v.42, n.7, p.1035-1042, 2007.

LARA-FLORES, M.; OLVERA-NOVOA, M.A.; GUZMÁNMÉNDEZ, B.E. et al. Use of the bacteria Streptococcus faecium and Lactobacillus acidophilus, and the yeast Saccharomyces cerevisiae as growth promoters in Nile tilapia (Oreochromis niloticus). Aquaculture, v.216, n.1-4, p.193-201, 2003.

LI, P.; GATLIN III, D.M. Evaluation of brewers yeast (Saccharomyces cerevisiae) as a feed supplement for hybrid striped bass (Morone chrysops x M. saxatilis). Aquaculture, v.219, n.1-4, p.681-692, 2003.

LI, P.;GATLIN III, D.M. Dietary brewers yeast and the prebiotic GrobiotickAE influence growth performance, immune responses and resistance of hybrid striped bass (Morone chrysops $\mathrm{M}$. saxatilis) to Streptococcus iniae infection. Aquaculture, v.231, n.5, p.445-456, 2004.

LI, P.; BURR, G.S.; GOFF, J. et al. A preliminary study on the effects of dietary supplementation of brewers yeast and nucleotides, singularly or in combination, on juvenile red drum (Sciaenops ocellatus). Aquaculture Research, v.36, n.11, p.1120-1127, 2005

LI, P.; GATLIN III, D.M. Evaluation of the prebiotic GroBioticR-A and brewers yeast as dietary supplements for sub-adult hybrid striped bass (Morone chrysops x M. saxatilis) challenged in situ with Mycobacterium marinum. Aquaculture, v.248, n.1-4, p.197-205, 2005.

MORAES, G.; MONZANI, P.S.S.; SOUZA, R.H.S. Aspectos do metabolismo nitrogenado de Piaractus mesopotamicus (pacu) sob estresse ambiental de $\mathrm{pH}$. Boletim Técnico do CEPTA, v. 8, p.61-74, 1995 .

NOGUEIRA, M.C.S.; CORRENTE, J.E. Decomposição da interação tripla significativa utilizando o comando contrast do proc $\mathrm{glm}$ do SAS aplicado ao modelo de classificação tripla para dados balanceados. Bragantia, v.59, n.1, p.109-115, 2000.

NOGUEIRA, M.C.S. Orthogonal contrasts: definitions and concepts. Scientia Agricola, v.61, n.1, p.118-124, 2004

OZÓRIO, R.O.A.; AVNIMELECH, Y.; CASTAGNOLLI, N. Sistemas intensivos fechados de produção de peixes. In: CYRINO, J.E.P.; URBINATI, E.; FRACAlOSSI, D. et al. (Eds.) Tópicos especiais em piscicultura de água doce tropical intensiva. São Paulo: TecArt, 2004. p.7-24

PAVANELli, G.C.; EIRAS, J.C.; TAKEMOTO, R.M. Doenças de peixes: profilaxia, diagnóstico e tratamento. 2.ed. Maringá: Eduem, 2002. 305p.

PEREIRA DA SILVA, E.M.; PEZZATO, L.E. Respostas da Tilápia do Nilo (Oreochromis niloticus) à atratividade e palatabilidade de ingredientes utilizados na alimentação de peixes. Revista Brasileira de Zootecnia, v.29, n.5, p.1273-1280, 2000 .

RIMMER, D.W.; WIEBE, W.J. Fermentative microbial digestion in herbivorous fishes. Journal of Fish Biology, v.31, n.2, p.229-236, 1987.

RODRÍGUEZ, A.; CUESTA, A.; ORTUNO, J. et al. Immunostimulan properties of a cell wall-modified whole Saccharomyces cerevisiae strain administered by diet to seabream (Sparus aurata L.). Veterinary Immunology and Immunopathology, v.96, n.3-4, p.183-192, 2003.

ROMERO, R.; GOMEZ-BASUARI, J. Yeast and yeast products, past present and future: from flavors to nutrition and health. Nutritional biotechnology in the feed and food industries. In: ALLTECH'S SYMPOSIUM, 19., 2003, Nottingham. Proceedings... Nottingham, 2003. p.365-371.

RUMSEY, G.L.; KINSELLA, J.E.; SHETTY, K.J. et al. Effect of high dietary concentrations of brewer's dried yeast on growth performance and liver uricase in rainbow trout (Oncorhynchus mykiss). Animal Feed Science and Technology, v.33, n.3-4, p.177-183, 1991a.

RUMSEY, G.L.; HUGHES, S.G.; SMITH, R.R. et al. Digestibility and energy values of intact, disrupted and extracts from brewer's dried yeast fed to rainbow trout (Oncorhynchus mykiss). Animal Feed Science and Technology, v.33, n.3-4, p.185-193, $1991 b$.

RUMSEY, G.L.; WINFREE, R.A.; HUGHES, S.T. Nutritional value of dietary nucleic acids and purine bases to rainbow trout (Oncorhynchus mykiss). Aquaculture, v.108, n.1-2, p.97-110, 1992.

SAKAI, M. Current research status of fish immunostimulants. Aquaculture, v.172, n.1-2, p.63-92, 1999.

SCAPINELLO, C.; FARIA, H.G.; FURLAN, A.C. et al. Efeito da utilização de oligossacarídeo manose e acidificantes sobre o desempenho de coelhos em crescimento. Revista Brasileira de Zootecnia, v.30, n.4, p.1272-1277, 2001a. 
SCAPINELLO, C.; FARIA, H.G.; FURLAN, A.C. et al. Efeito do uso de oligossacarídeo manose e acidificantes em rações com alto teor de amido, para coelhos em crescimento. Acta Scientiarum, v.23, n.4, p.1039-1043, 2001b.

SGARBIERI, V.C.; ALVIM, I.D.; VILELA, V.L.S. et al. Produção piloto de derivados de levedura (Saccharomyces sp.) para uso como ingrediente na formulação de alimentos. Brazilian
Journal of Food Technology, v.2, n.1-2, p.119-125, 1999.

SMITH, T.B.; WAHL, D.H.; MACKIE, R.L. Volatile fatty acids and anaerobic fermentation in temperate piscivorous and omnivorous freshwater fish. Journal of fish Biology, v.48, n.5, p.829-841, 1996.

STATISTICAL ANALYSIS SYSTEMS - SAS. SAS 9.1 for windows. Cary: 2004. 5136p. 